\title{
Evaluating the Impact of Two Dialogical Feedback Methods for Improving Pre-Service Teacher's Perceived Confidence and Competence to Teach Physical Education Within Authentic Learning Environments
}

\author{
Narelle Eather ${ }^{1,2}$, Nicholas Riley ${ }^{1,2}$, Drew Miller ${ }^{1,2}$, Scott Imig ${ }^{2}$ \\ ${ }^{1}$ Priority Research Centre in Physical Activity and Nutrition, School of Education, University of Newcastle, Callaghan \\ Campus, Newcastle, Australia \\ ${ }^{2}$ University of Newcastle, Australia \\ Correspondence: Narelle Eather, Priority Research Centre in Physical Activity and Nutrition, School of Education, \\ University of Newcastle, Callaghan Campus, Newcastle, Australia; University of Newcastle, Australia.
}

Received: February 12, 2019

doi:10.11114/jets.v7i8.4053
Accepted: March 1, 2019 Online Published: June 17, 2019

URL: https://doi.org/10.11114/jets.v7i8.4053

\begin{abstract}
This novel study investigates the effectiveness of two dialogical feedback methods, peer dialogue assessment and dialogical feedback provided by an academic, when they are used as assessment as learning tools in undergraduate physical education courses. Education students from the University of Newcastle, Australia $(n=288)$, participated in this investigation and completed eight weeks of face-to-face on-campus physical education studies followed by a 3 or 4 week in-school teaching program ( 1.5 hrs/week). Students engaged in either peer dialogue assessment or dialogue provided by an academic at the completion of each concurrent teaching session with their respective peer group or academic. Both feedback groups exhibited equivalent and significant improvements in teaching self-efficacy, teaching competence and teaching confidence. This study provides support for embedding formative assessment tasks in an authentic teaching environment in undergraduate physical education courses, and using dialogical feedback (peer or academic) to facilitate reflection and furthering learning in this context.
\end{abstract}

Keywords: teacher education, physical education, dialogue; feedback, assessment, authentic learning environment

\section{Introduction}

There is ongoing exploration of ways to improve and maximise student learning within Higher Education (HE) programs (Evans, 2013; McAleese et al., 2013). Authentic learning environments, assessment and feedback are crucial components of the learning process (Adcroft, 2011; Carless, Salter, Yang, \& Lam, 2011; L. Darling-Hammond, 2006; Hattie and Timperley, 2007; Tony and Jan, 2006). Authentic learning experiences refer to learning experiences that are personally relevant from the perspective of the learner, and are situated within appropriate social contexts (Iucu and Marin, 2014; Tony and Jan, 2006). In the course of preparing school teachers in HE programs, providing opportunities to practice and learn within authentic learning environments (i.e., teaching children in school) allows engagment in realistic and relevent tasks using real-world resources and equipment, and offers real-world problems (Herrington, Parker, \& Boase-Jelinek, 2014; Shulman, 1987; Stein, Isaacs, \& Andrews, 2004). It also provides opportunities for pre-service teachers to learn purposefuly (e.g., by thinking and behaving like teachers do in school settings); and when reflective practices are developed and promoted, enables them to become thoughtful and effective teachers focused on quality teaching and learning (Cochran-Smith et al., 2015; Herrington, et al., 2014). Consequently, HE institutions continue to seek increased and diverse opportunities for pre-service teachers to learn in authentic environments (such as work integrated learning or school placements), in order to better prepare future teachers for the demands they will face in schools (K. Zeichner, 2010).

The value of assessment as a learning tool is well documented (Ashenafi, 2017). However, the literature on assessment practices within HE promotes a need for change in order to enhance student learning (Carless, et al., 2011; Shepard, 2000). Specifically, there is a demand for academics to shift the focus from traditional and typically content-heavy summative assessment tasks (Ellery, 2008; Long, 2014). Formative assessments have shown to be more effective for 
facilitating learning when they are authentic (i.e., assess work-related competencies), student-centred and designed to provide support and feedback to students. Effective assessments also help students develop reflective practices, monitor their own progress and identify their strengths and weaknesses (Ashford-Rowe, Herrington, \& Brown, 2014; Evans, 2013). For the purposes of learning and development, formative assessments that hold no summative value (or bearing on grades) have shown to be particularly effective in teaching-learning environments (Wiliam, 2017).

Importantly, research supports that the provision of feedback is essential for improving knowledge and skill acquisition, and facilitating reflection and development (Adcroft, 2011; Carless, et al., 2011; Costa and Garmston, 2002; Doan, 2013; Hattie and Timperley, 2007; Weaver, 2006). Feedback generally refers to any information provided to an individual as a result of an assessment of performance (Black and Wiliam, 1998); and in the context of HE, may lead to a change in student work or learning strategies implimented by an academic. Feedback has shown to be most effective when the information provided helps identify disparities between a student's current level of performance and the intended level of performance (or learning outcome), suggestions are provided to the student on how to move towards outcome attainment, and students are given the opportunity to use the information provided to plan for and deliver subsequent performances (Shute, 2008). Despite the large body of research on this topic, the concept of feedback and the specific mechanisms linking feedback to learning are commonly misunderstood (Orsmond, Maw, Park, Gomez, \& Crook, 2013). Furthermore, evidence supports that students in HE appreciate and want good feedback to improve (Higgins, Hartley, \& Skelton, 2002; Orsmond, Merry, \& Reiling, 2005), but students and academics continually report dissatisfaction with existing feedback processes (M. Price, Handley, Millar, \& O'Donovan, 2010).

Traditionally in HE, providing written comments on a student's assignment or about a student's performance has been the primary source of feedback provided to students (Nicol, 2010). However, HE students claim that the written feedback provided by academics is not helpful for their learning, and academics report the burden of giving written feedback that is often not read or used (Adcroft, 2011; Boud, 2015; Carless, 2006; Carless, et al., 2011; Kluger and DeNisi, 1996; L. McDowell, Smailes, Sambell, Sambell, \& Wakelin, 2008; Nicol, 2010). The current situation in many HE institutions is unproductive for academics and students, and suggests that the usefulness of feedback as a tool for enhancing student learning is not being effectively utilized (Margaret Price, Handley, \& Millar, 2011). The literature also supports that one-way communication, or simply transmitting written or spoken information, leads to little learning (Nicol, 2009, 2010). Archer (2010) and Nicol (2010) suggest that for students to learn, feedback needs to be facilitative, and students must do something with transmitted information (i.e., analyse it, ask questions about it, discuss it with others, connect it with prior understanding and use it to inform future actions) (Archer, 2010; Nicol, 2010). Despite the fact that high quality written feedback can provide valuable information, it has shown to be ineffective as a feedback tool in HE, and there has been a slow shift away from academics providing students with written feedback only. Now the focus is on developing novel feedback methods that promote student interaction and facilitate student learning in an enabling environment (Boud, 2015; Boud and Molloy, 2013; Hattie and Timperley, 2007; Long, 2014; Liz McDowell, Wakelin, Montgomery, \& King, 2011; Weaver, 2006).

Including dialogue (or verbal discussion) as part of the feedback process for students has been a common strategy used in HE. Usually, feedback dialogues involve collaborative discussions about feedback between an academic and a student (or group of students), which provides opportunity for shared understandings, clarification and questioning (Blair and McGinty, 2013). There is a growing body of research supporting the importance of feedback in the form of dialogue as a vessel for facilitating learning (Blair and McGinty, 2013; Nicol, 2010). Instead of written feedback, students prefer and engage more in dialogue with academics because the feedback is usually easier to understand and more personal, academic terminology can be explained or clarified where needed, and questions or concerns can be addressed instantaneously (Weaver, 2006) - overcoming some of the key issues expressed by students exposed to traditional written feedback methods. However, the effectiveness of academic-student dialogue can be hindered when power relationships exists, when students and academics have differing expectations or understandings of feedback, when the feedback process moves away from a participatory process (to verbal transmission of information), or students are not given the opportunity to use the feedback to improve their work (Blair and McGinty, 2013). Furthermore, providing dialogue between academic and student presents serious challenges in the current climate of HE, especially given class sizes, professional expectations on faculty members and resource / budget constraints.

In the context of HE, exploring the student's role in the feedback process is now a dominant research focus (Merry, Price, Carless, \& Taras, 2013). Boud and Falchikov (2007) promote that the learning experience is optimised for students when they understand the feedback process and explicitly learn to become assessors, not just be assessed by others (Boud and Falchikov, 2007). Through this engagement in the feedback-learning process, students are involved in making (rather than merely receiving) judgments within the specific learning context - leading to a better understanding of feedback (Claxton, Chambers, Powell, \& Lucas, 2011; M. Price, et al., 2010). Peer-assessment is a common practice in HE and involves learners of equal status providing feedback (Ashenafi, 2017; Brown, 2010; Cartney, 2010; Gielen, 
Peeters, Dochy, Onghena, \& Struyven, 2010; Nicol, 2010; Rust, 2007; Sadler, 2010). The main difference between academic and peer feedback is that peers are not experts, whereas academics are trained professionals in their respective fields. Consequently, the accuracy and quality of peer feedback fluctuates (Gielen, et al., 2010). Despite this, studies have shown that HE students who are trained in, and provide their peers with high-quality feedback, are more likely to incorporate feedback from their peers effectively, and perform better - especially when they receive feedback from multiple peers and have the opportunity to use peer feedback to make revisions of their work (Ashenafi, 2017). Despite extensive investigations, peer-assessment practices have changed very little in the past 50 years and high quality effectiveness trials are lacking (Evans, 2013). Based on the available literature, it is recommended that students be trained in peer assessment processes, peer assessment be performed in small groups using clear formative goals (or an assessment framework), and feedback be orally explained and discussed with the assessed peer in order for feedback to be useful for learning (Ashenafi, 2017; van Zundert, Sluijsmans, \& van Merriënboer, 2010).

Peer dialogue assessment (PDA) is a relatively new peer-driven dialogical method of feedback showing potential as an effective and sustainable learning strategy for students in HE programs and clinical settings (Bok et al., 2013; Eather, Riley, Miller, \& Jones, 2017; Molloy and Boud, 2013; Nicol, 2010). PDA situates students or learners as active participants in the feedback cycle, where they seek, generate and use feedback in the form of dialogue provided by peers to self-regulate performance on future tasks (Evans, 2013). Generally, during a PDA session, students observe their peers during a task or an assessment and engage in a structured conversation about their performance. The students observing a performance stimulate the dialogue by asking questions that elicit rationalised responses and justifications regarding the observed performance (Eather, et al., 2017). In order for PDA to elicit high quality feedback and self-reflection, pre-determined evaluation criteria or frameworks should guide the dialogue (to avoid opinion-based questioning) and students should have training and practice in PDA methods. This process of PDA facilitates a deeper understanding of content knowledge, stimulates higher order thinking skills and keeps students accountable for their preparation. By taking this approach to assessment, academics can move away from viewing feedback as a product provided by academics (e.g., written feedback), towards a long-term dialogic process in which both students and academics are engaged (Margaret Price, et al., 2011). Initial investigations support that students like and value PDA, and academics report that it promotes self-directed learning and enhances student self-evaluative abilities (especially when multiple opportunities are provided for students to use PDA to improve subsequent performances) (Eather, et al., 2017; Molloy and Boud, 2013; Tschannen-Moran and Woolfolk Hoy, 2001).

In HE, formative assessment that engage peers in the feedback process can be extremely valuable for learning, particularly when programs implement peer assessment throughout the duration of the educational program (Ellery, 2008). Despite the constraints for developing such programs in existing HE courses, preliminary evidence supports the usefulness of formative peer assessed tasks, specifically those that include peer dialogue and offer multiple opportunities for feedback (rather than 'one-off' tasks). Our research team recently demonstrated that when thirty six undergraduate physical education students were provided with instruction and practice using PDA, and implemented PDA following consecutive teaching performances, they exhibit significant improvements in perceived teaching confidence and competence, and teaching self-efficacy (Eather, et al., 2017). However, despite having training and practice in conducting PDA, and a framework for guiding dialogue content, the quality of the dialogue of the feedback provided by students varied greatly. Similarly, Cartney (2010) conducted an exploration into the value of PDA as a formative and formal 'assessment for learning' strategy for use in HE, but also included dialogue between students and tutors and written feedback in their feedback process. Cartney found that participants recognised the professional benefits of sharing knowledge and ideas with peers as essential for future professional as well as academic development (Cartney, 2010). However, in Cartney's study it is unclear which element of the dialog (peer-peer or academic-peer) was most valuable for learning.

Evidence shows effective teachers are the most important in-school contributors to student learning, (Linda Darling-Hammond, 2000; Hattie, 2003 October; Sanders, Wright, \& Horn, 1997). Importantly, a physical education teacher's competence can significantly impact on the well-being and development of children in multiple domains (e.g., physical, affective, social, and cognitive) - both in the short and long term (Bailey et al., 2009; Dudley, Okely, Pearson, \& Cotton, 2011; Institute of Medicine, 2013; Jenkinson and Benson, 2010; P.J. Morgan and Hansen, 2007; Society of Health and Physical Educators, 2010). Therefore, the aim of this experimental investigation was to evaluate and compare the effectiveness of using two types of dialogical feedback (provided by peers and academic) for improving undergraduate physical education students perceived teaching confidence and competence, and teaching self-efficacy when embedded as an assessment for learning tool within an authentic learning experience. 


\section{Methods}

Design

The study design was a two-arm randomised controlled trial conducted over two academic semesters in 2017. Assessments were conducted at baseline and immediately post-intervention (14 weeks). Participants were randomized by class into the PDA or AD conditions; with an academic experienced with teaching and conducting PDA timetabled on half of the classes. The University of Newcastle Human Research Ethics Committee provided ethics approval for the study.

\section{Participants}

For this trial all undergraduate Bachelor of Teaching (Health and Physical Education and Primary) students from the University of Newcastle, Australia, enrolled in physical education courses involving in-school teaching experiences in 2017 were invited to participate. In accordance to ethics guidelines, an independent $3^{\text {rd }}$ party (other than the research team) was responsible for recruiting participants and for administering the questionnaires to minimise coercion. Those students with informed signed consent were eligible to complete assessments, but all students enrolled in the course completed the standard coursework.

\section{Context}

The physical education courses included in this study involved 8 weeks of on-campus studies and a 3- or 4-week in-school teaching experience conducted during one semester of the year. Each course involved the development and application of a student's pedagogical knowledge and skills relating to a range of games and sports, with a focus on high quality delivery of physical education using an organisational framework (OMG-TEST)(Miller et al., 2016) and the Supportive, Active, Autonomous, Fair, Enjoyable (SAAFE) principles (Lubans et al., 2017). The SAAFE principles represent an evidence-based framework designed to guide the planning, delivery and evaluation of organized physical activity and physical education sessions in school, community sport and after school programs.

\section{PDA Conditions}

Weeks 1-8: PDA was introduced to participating students as a compulsory component of their 12-week physical education course (12 weeks of study plus 2 weeks mid-semester break = one semester). Students learned about the value of PDA as a learning tool to improve their teaching practices (via a discussion of current research) and were given written examples of how PDA can be structured within the context of teaching physical education. Students were provided with information and opportunities to build their skills in stimulating dialogue to provide feedback on teaching performance within selected practical tutorial activities (approximately 15 minutes each week). This dialogue was facilitated by the university tutor (who was trained in the delivery of PDA); and was guided by an instructional framework (Miller, et al., 2016) and the SAAFE teaching principles (Supportive, Active, Autonomous, Fair and Enjoyable) (Lubans, et al., 2017) outlined in Table1.

Week 9-12 (or 10-12 for EDUC2747): The students participated in a 3 or 4 week in-school teaching program (1.5 hours per week) where they worked in teams of four ( $2 \mathrm{x}$ pairs) to plan and teach school physical education for $45 \mathrm{~min}$ and to observe their partner peer group teaching for 45 minutes each week. The students were provided with observation sheets outlining the SAAFE principles and OMG-TEST organisational framework (with question example) to draft questions, and were required to use PDA at the completion of each of the three or four concurrent teaching sessions to provide feedback to their respective peer group (approximately 10-20 minutes per session).

\section{Academic Dialogue (AD) Conditions}

Weeks 1-8: AD was introduced to participating students as a compulsory component of their 12-week physical education course (one semester). Students learned about the value of AD as a learning tool to improve their teaching practices and were given opportunities to engage in AD within selected practical tutorial activities (approximately 15 minutes each week). This dialogue was facilitated by the university tutor; and was also guided by an instructional framework (Miller, et al., 2016) and the SAAFE teaching principles (Supportive, Active, Autonomous, Fair and Enjoyable) (Lubans, et al., 2017).

Week 9-12 (or 10-12 for EDUC2747): The students participated in a 3 or 4 week in-school teaching program (1.5 hours per week) where they worked in teams of four ( $2 \mathrm{x}$ pairs) to plan and teach secondary school physical education for $45 \mathrm{~min}$ and to observe their partner peer group teaching for 45 minutes each week. The students were required to engage in $\mathrm{AD}$ at the completion of each of the three or four concurrent teaching sessions (approximately 10-15 minutes per session). 
Table 1. Instructional framework for organising games and SAAFE Teaching Principles

\begin{tabular}{|c|c|c|c|}
\hline \multicolumn{3}{|c|}{ Instructional framework (OMG TEST) } & \multirow{2}{*}{$\begin{array}{l}\text { SAAFE teaching principles } \\
\text { 1. Teacher provides individual skill specific feedback } \\
\text { 2. Teacher provides feedback on student effort and involvement } \\
\text { 3. Teacher promotes positive interactions between students }\end{array}$} \\
\hline $\mathbf{O}$ & $\begin{array}{l}\text { Teacher organises the } \\
\text { groups quickly }\end{array}$ & Supportive & \\
\hline M & $\begin{array}{l}\text { Teacher moves students } \\
\text { into the GO position } \\
\text { efficiently }\end{array}$ & Active & $\begin{array}{l}\text { 1. Activities involve small-sided games or tabloids involving all } \\
\text { students } \\
\text { 2. Equipment is plentiful and developmentally appropriate } \\
\text { 3. Transitions between activities are efficient }\end{array}$ \\
\hline G & $\begin{array}{l}\text { Teacher gives instructions } \\
\text { and demonstration } \\
\text { simultaneously }\end{array}$ & Autonomous & $\begin{array}{l}\text { 1. Some activities incorporate multiple challenge levels } \\
\text { 2. Students are given choices about the tasks and activities } \\
\text { 3. Students are involved in the set-up, decision-making or running of } \\
\text { activities }\end{array}$ \\
\hline $\mathbf{T}$ & $\begin{array}{l}\text { Students try the game / } \\
\text { activity }\end{array}$ & Fair & $\begin{array}{l}\text { 1. Teacher ensures that students are evenly matched in activities } \\
\text { 2. Teacher acknowledges and rewards good sportsmanship } \\
\text { 3. If necessary, teacher modifies activities to maximise opportunities } \\
\text { for success }\end{array}$ \\
\hline $\mathbf{E}$ & $\begin{array}{l}\text { Teacher is observing and } \\
\text { evaluates the game - } \\
\text { providing individual / } \\
\text { group feedback where } \\
\text { appropriate }\end{array}$ & Enjoyable & $\begin{array}{l}\text { 1. Lesson starts with an enjoyable activity and concludes with an } \\
\text { enjoyable experience } \\
\text { 2. Activities are meaningful, appropriate and not repetitive } \\
\text { 3. Lessons involve a wide range of appropriate activities (based on } \\
\text { the lesson focus) }\end{array}$ \\
\hline $\mathbf{S}$ & \multicolumn{3}{|c|}{ Stop! The teacher stops the game to modify the game or attach learning to the activity } \\
\hline $\mathbf{T}$ & git tivat ace & & \\
\hline
\end{tabular}

Measures

In order to evaluate and compare the effectiveness of PDA and AD for improving pre-service teachers' confidence and competence to teach physical education, and teaching self-efficacy the following measures were undertaken at pre and post intervention:

1. A purpose-designed questionnaire was completed by participants at baseline and at follow-up (14 weeks). The questionnaire was based on previously used and published scales (adapted to suit the teaching of physical education and sports in secondary schools) to determine participant:

a. Competence to teach PE (P. J. Morgan and Bourke, 2005; P. J. Morgan and Bourke, 2008) and competence to teach invasion games: twenty two (22) self-report items rating general competence to teach PE (11 items) and competence to teach invasion games (11 items) were given using a 5-point Likert scale ranging from 'Not Competent at all' to 'Completely competent' (e.g., Lesson planning for PE......).

b. Confidence to teach PE in general (Hand, 2014) and confidence to teach invasion games: twenty eight (24) self-report items rating confidence to teach invasion games were given using a 5-point Likert scale (24 items) ranging from 'Not Competent at all' to 'Completely competent' (e.g., My ability to explain game sense concepts relating to skilful movement and game play in invasion games......) and four (4) open-ended questions (e.g., please indicate the factors that most influenced your current level of confidence in teaching invasion games).

c. Self-efficacy to teach (Tschannen-Moran and Woolfolk Hoy, 2001): twenty four (24) self-report items rating confidence to teach invasion games were given using a 5-point Likert scale (24 items) ranging from 'Not at all' to 'A great deal' (e.g., How much can you do to get through to the most difficult students?)

2. Process evaluation: The feasibility of the programme was examined using a number of measures. In order to evaluate the quality, quantity and relevance of PDA group discussions, participants were asked to move to a private area at the end of each teaching session to discuss their teaching performances and to audio record the sessions (using the provided 
iPad). The recordings were uploaded after each session and then transcribed and entered into a database at the completion of the study. Measures of recruitment (evaluation of the recruitment process, dissemination of information and obtaining informed consent), retention (measure of how many students completed the program and participated in all assessments pre- and post-intervention), adherence (evaluation of the degree to which participants followed the PDA and AD program) and satisfaction (level of satisfaction and engagement with PDA as a learning tool) were used.

\section{Statistical Analysis}

Statistical analyses of all outcomes was conducted using linear mixed models using IBM SPSS Statistics for Windows (Version 20) (SPSS, INC 2010, IBM Company, Armonk, NY) with alpha levels set to 0.05. Linear mixed models were used to assess the impact of treatment (PDA or AD group), time (treated as categorical with levels that include baseline and immediate post-intervention follow-up) and the group-by-time interaction. Mixed models are consistent with the intention-to-treat principle and retain all randomized participants in the analysis, regardless of whether or not they drop out of the study.

PDA discussions were audio-recorded, transcribed by an independent company, and then entered into a database. Transcriptions were then analysed based on the SAAFE teaching principles (Lubans, et al., 2017) and the instructional framework (Miller, et al., 2016) outlined in Table 1. Using a recursive approach, relevant quotes with similar meanings were grouped together under the appropriate principle and / or theme (Whitehead and Biddle, 2008).

\section{Results}

\section{Primary Outcomes}

In summary, this study involved 288 undergraduate students enrolled in four pre-service teacher education courses $(63.5 \%$ female; PDA $66.7 \%$ female; AD 59.5\% female) at the University of Newcastle, NSW Australia. All invited students consented to participate in the study.

In this study, there were no significant differences between treatment groups for any measures of self-reported teaching competence, confidence and self-efficacy ( $p>0.05)$. Within group analysis showed significant improvements in both groups for all outcomes: teaching self-efficacy (mean change (out of 5) PDA: +0.428 ; AD: +0.345 ); perceived teaching competence (total score)(mean change PDA: +0.871 ; AD: +0.895 ); and confidence to teach (total score) (PDA: +0.912 ; AD: +0.894$)(\mathrm{p}<0.001$ for all measures). Results for all measures and subscales are presented in Table 2.

\section{Process Evaluation Results}

\section{PDA Themes}

Based on the instructional framework for organising games (OMG-TEST), and SAAFE Teaching Principles, audio files were transcribed and analysed for themes (Table 3). Despite the fact that some students combined comments and questions (rather than posing questions only), there were 567 relevant discussion points extracted from the PDA audio files and a breakdown of the content themes and major focus points are presented in Table 4. [Insert Table 4 near here]. Our analysis revealed that specific themes were more popular during PDA sessions. Despite having instruction and practice using the instructional framework and all elements of SAAFE teaching principles, a large proportion of the discussion points $(\sim 40 \%)$ focused on the instructional framework (e.g., improving teaching strategies for transition efficiently between activities, forming groups effectively, and providing effective instructions and demonstrations). Realistically, these elements of teaching are easiest to change or improve though simple measures, and participants in this study may have felt informed enough to discuss these issues confidently with their peers. Although 54\% of discussion points focused on the SAAFE principles, students opted to discuss issues around providing a supportive environment for children (18\%) and maximising active learning time (14\%), in preference to the principles of autonomy (8\%), fair (5\%) and enjoyable (11\%). Additional discussion points and questions relating to behaviour management (6\%) were noted.

The feasibility of embedding PDA and AD as assessment for learning tools within existing undergraduate physical education course was confirmed. Our evaluation revealed 1) a recruitment rate of $100 \%$ (with all 288 students in attendance of the recruitment presentation in week 1 of physical education courses agreeing to participate); 2) satisfactory retention (with $78.5 \%$ of participants in attendance for follow-up assessments at 14-weeks); and 3) excellent program adherence (with all university tutorial sessions delivered, all in-school visits being conducted and participant attendance at the tutorial sessions and in-school visits being $>80 \%$ and $>95 \%$ respectively). It should be noted that embedding the PDA and AD into existing physical education courses may impact on retention and adherence results. In this circumstance, drop-out from university impacts on retention rates, and the captive audience within university courses improves the likelihood of adherence to the program. Satisfaction data collected at the completion of the study and course evaluation surveys revealed that participants generally found PDA and AD to be useful tool for learning in physical education and provided positive feedback for embedding these two types of feedback within courses that 
provide authentic learning opportunities (i.e., consecutive teaching sessions in schools). For example: students provided a mean overall satisfaction score of 4.7 out of 5 for the physical education courses in this study, and rated them highly with regard to learning (mean score 4.6 / 5), assessment (mean score 4.6 / 5), and relevance (4.7 / 5). Students were also asked to provide qualitative feedback on the use of authentic learning environments. Responses were analysed and three main categories were identified. For each category, example statements are provided in Table 4.

Table 2. Treatment effects (Peer Dialogue Assessment vs Academic Dialogue) (Australia, 2017)

\begin{tabular}{|c|c|c|c|c|c|c|c|c|c|c|}
\hline \multirow[b]{3}{*}{ Measure } & \multicolumn{10}{|c|}{ Physiological Outcomes } \\
\hline & \multicolumn{4}{|c|}{ Academic Dialogue } & \multicolumn{4}{|c|}{ Peer Dialogue Assessment } & \multirow{2}{*}{$\begin{array}{c}\text { Adjusted } \\
\text { Difference in } \\
\text { Change (95\% } \\
\text { CI) } \\
\end{array}$} & \multirow[b]{2}{*}{$\begin{array}{c}\text { Group } * \text { Time } \\
P \text { value }\end{array}$} \\
\hline & $\begin{array}{l}\text { Baseline } \\
(n=126)\end{array}$ & SD & $\begin{array}{c}\text { 14weeks } \\
(n=92)\end{array}$ & SD & $\begin{array}{l}\text { Baseline } \\
(n=162)\end{array}$ & SD & $\begin{array}{c}\text { 14weeks } \\
(\mathbf{n}= \\
134)\end{array}$ & SD & & \\
\hline TSES & 3.68 & 0.60 & 4.05 & 0.53 & 3.71 & 0.54 & 4.13 & 0.45 & $\begin{array}{c}0.08 \\
(-0.77-2.44)\end{array}$ & 0.307 \\
\hline $\begin{array}{l}\text { Competence } \\
\text { to teach PE } \\
\text { (total score) }\end{array}$ & 3.14 & 0.66 & 4.04 & 0.45 & 3.19 & 0.54 & 4.06 & 0.38 & $\begin{array}{c}-0.02 \\
(-0.20-0.15)\end{array}$ & 0.789 \\
\hline $\begin{array}{l}\text { Competence } \\
\text { to teach PE } \\
\text { (in general) }\end{array}$ & 2.89 & 0.74 & 3.97 & 0.49 & 2.93 & 0.66 & 3.99 & 0.41 & $\begin{array}{c}-0.03 \\
(-0.23-0.17)\end{array}$ & 0.749 \\
\hline $\begin{array}{l}\text { Competence } \\
\text { to teach PE } \\
\text { (student } \\
\text { outcomes) }\end{array}$ & 3.37 & 0.68 & 4.10 & 0.48 & 3.41 & 0.55 & 4.13 & 0.46 & $\begin{array}{c}0.00 \\
(-0.20-0.18)\end{array}$ & 0.928 \\
\hline $\begin{array}{l}\text { Confidence to } \\
\text { teach PE } \\
\text { (total score) }\end{array}$ & 3.08 & 0.64 & 3.98 & 0.52 & 3.16 & 0.57 & 4.07 & 0.45 & $\begin{array}{c}0.02 \\
(-0.18-0.21)\end{array}$ & 0.860 \\
\hline $\begin{array}{l}\text { Confidence to } \\
\text { teach PE } \\
\text { (teaching) }\end{array}$ & 2.96 & 0.81 & 3.91 & 0.57 & 3.01 & 0.69 & 4.00 & 0.42 & $\begin{array}{c}0.04 \\
(-1.78-0.26)\end{array}$ & 0.699 \\
\hline $\begin{array}{l}\text { Confidence to } \\
\text { teach PE } \\
\text { (planning) }\end{array}$ & 2.90 & 0.83 & 3.96 & 0.59 & 3.05 & 0.70 & 4.00 & 0.45 & $\begin{array}{c}-0.11 \\
(-0.34-0.12)\end{array}$ & 0.333 \\
\hline $\begin{array}{l}\text { Confidence to } \\
\text { teach PE } \\
\text { (instructing) }\end{array}$ & 3.13 & 0.70 & 3.96 & 0.64 & 3.22 & 0.62 & 4.10 & 0.57 & $\begin{array}{c}0.06 \\
(-0.16-0.28)\end{array}$ & 0.572 \\
\hline $\begin{array}{l}\text { Confidence to } \\
\text { teach PE } \\
\text { (professional } \\
\text { development) }\end{array}$ & 3.23 & 0.67 & 4.03 & 0.52 & 3.26 & 0.65 & 4.12 & 0.60 & $\begin{array}{c}0.06 \\
(-0.17-0.28)\end{array}$ & 0.604 \\
\hline
\end{tabular}

Abbreviations: TSES: Teaching Self-Efficacy Scale; CI, confidence interval; SD, standard deviation; adjusted mean difference and 95\% CI between Peer Dialogue Assessment and Academic Dialogue groups after 14-weeks (PDA - AD) -adjusted for baseline scores;

Table 3. PDA Themes (Australia, 2017)

\begin{tabular}{lll}
\hline Theme & n & Focus Points \\
\hline Supportive & 101 & $\begin{array}{l}\text { Use of feedback during teaching (positive and constructive) } \\
\text { Use of motivational strategies } \\
\text { Provision of encouragement and praise }\end{array}$ \\
\hline Active & 79 & $\begin{array}{l}\text { Organising activities to maximise active learning time } \\
\text { Activity choice for involving all students in class activities } \\
\text { Changing activity structure / rules to involve all students }\end{array}$ \\
\hline Autonomous & 44 & $\begin{array}{l}\text { Student's contribution to changing the rules of a game and set up } \\
\text { Student choice of teams } \\
\text { Students given choice of roles in games / activities }\end{array}$ \\
\hline Fair & 26 & $\begin{array}{l}\text { Changing the rules and organisation of teams to make the game fair for all } \\
\text { Implementing changes to rules / activity structure to maximise success } \\
\text { Grouping students based on skill levels }\end{array}$ \\
\hline Enjoyment & 60 & $\begin{array}{l}\text { Activity choices to increase enjoyment } \\
\text { Games vs skill / drill approach } \\
\text { Implementing changes to games to minimise boredom }\end{array}$ \\
\hline OMG-Test & 223 & $\begin{array}{l}\text { Minimising transition time } \\
\text { Explicit instructions } \\
\text { Group organisation }\end{array}$ \\
\hline Other & 34 & $\begin{array}{l}\text { Behaviour management strategies for engaging disengaged students in lesson activities } \\
\text { Minimising transition time to reduce behaviour problems }\end{array}$ \\
\hline Total & 567 & \\
\hline
\end{tabular}


Table 4. Students' feedback on the use of authentic learning environments (Australia, 2017)

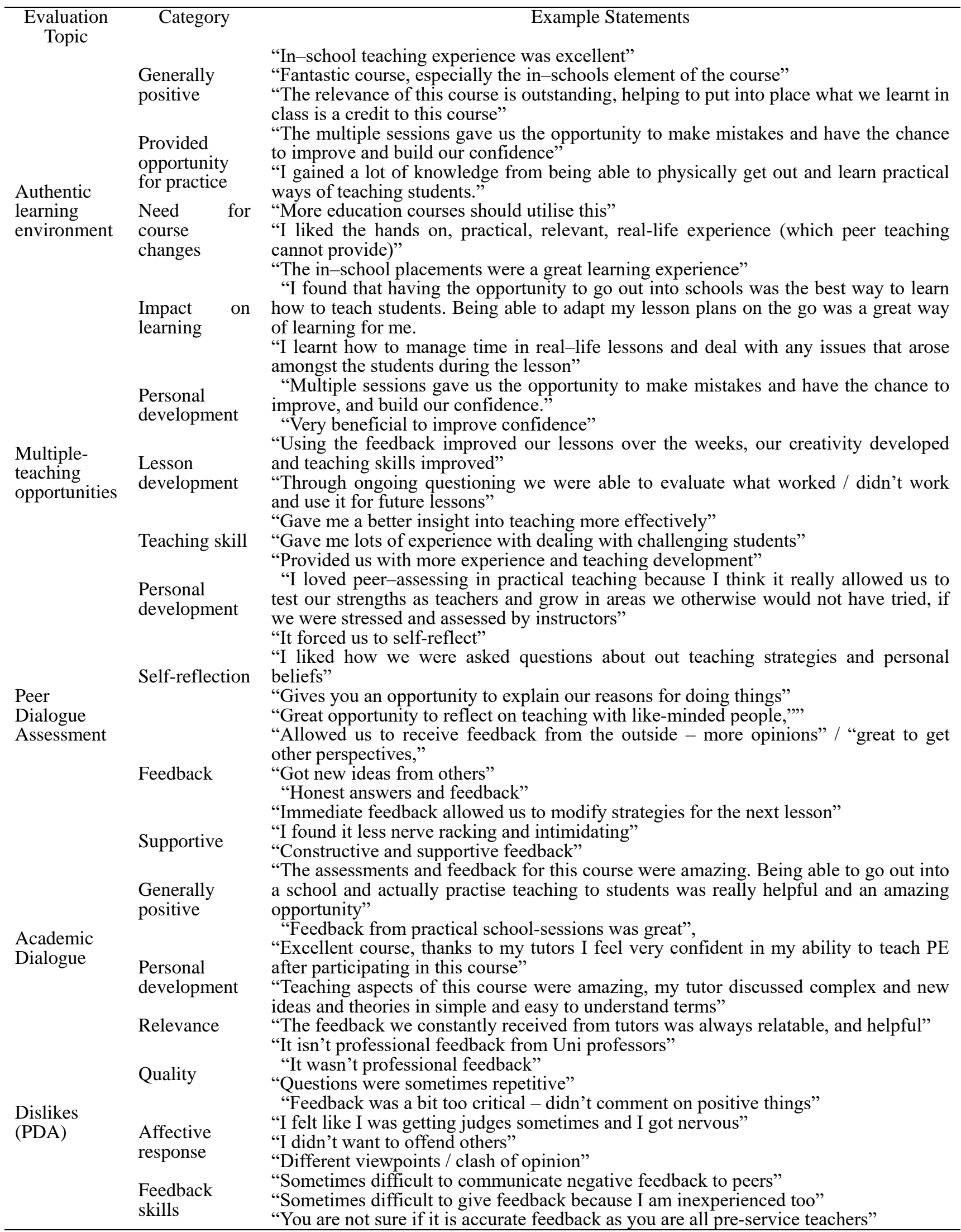




\section{Discussion}

This novel study demonstrates that the use of dialogue as feedback, whether it be academic or peer facilitated, is an effective tool for improving self-perceptions of pre-service teachers. Our results show that undergraduate students studying physical education improved self-reported teaching competence, confidence and self-efficacy using dialogical feedback (peer or academic) following multiple and consecutive in-school teaching experiences - with the use of peer-dialogue equally impactful as academic feedback. The positive feedback provided by students also implies that using dialogue as an assessment for learning tool may be an effective and well-received approach to learning.

A teacher's perceptions of his or her ability to teach and confidence to teach is often related to the attainment of core student outcomes (Bandura, 1977). Our positive findings regarding self-perceptions of teaching are particularly important because evidence suggests that teachers who have high levels of teaching efficacy (a judgment of his/her capabilities to bring about desired outcomes of student engagement and learning (Tschannen-Moran and Woolfolk Hoy, 2001)), are more likely to be open to new ideas and to develop positive teaching attitudes. They are also shown to be more capable of using multiple instructional strategies effectively and facilitating student engagement in class, more successful in classroom management skills, and make more effort to overcome teaching-related problems they encounter (Ozder, 2011). Given the potential impact of teaching self-perceptions on a pre-service teacher's success in the future, pre-service teacher education programs would benefit from including evidence-based strategies that specifically target the development of these psychological outcomes. Previous work by Morgan and Bourke (2005) highlighted the strong relationship existing between teachers' training in physical education and their perceived confidence to teach physical education (P.J. Morgan and Hansen, 2007). This study extends our previous investigation of PDA (Eather, et al., 2017) but demonstrates that including peer or academic dialogical feedback provided after consecutive teaching performances is an effective tool for improving all aspects of teaching competence, confidence and self-efficacy in pre-service primary and secondary teachers delivering physical education classes.

Providing an authentic learning environment for pre-service teachers has shown to be effective for learning. The literature supports that students in the $21^{\text {st }}$ century are more motivated and engaged in learning new concepts and skills when they are interested in what they are learning, when the learning prepares them to succeed in a variety of situations, and the learning context is relevant and applicable to their future (outside of studies) (Iucu and Marin, 2014). Additionally, Lucu (2014) promotes that an authentic learning environment should provide students with coaching and scaffolding, opportunities to reflect and collaborate, and encourage students to verbalise their knowledge and thinking (Iucu and Marin, 2014). In this study, pre-service teachers were provided with evidence-based frameworks for delivering and evaluating teaching practices, and were involved in specific training in providing, receiving and understanding feedback through dialogue during their semester long physical education courses. They were also provided three or four consecutive teaching opportunities in a local primary or secondary school (specific to their program), and they were required to plan, implement and evaluate the lessons. Timetabling one lesson per week enabled the pre-service teachers to use the dialogical feedback provided by peers or an academic to reflect on their lessons (positive and negative aspects) and to strengthen their lesson planning and teaching practices in subsequent weeks. In the past, peer teaching has been a common learning or assessment practice in physical teacher education courses at our institution, whereby undergraduate students practiced their teaching on fellow pre-service teachers in the University setting. Although this is a time-efficient and convenient way to practice teaching skills during on-campus tutorials, most of the 'real-world' factors faced by teachers in the classroom are lacking (e.g., behaviour management, variation in skill and knowledge levels, limited resources or facilities). Through the creation of an on-going and authentic learning environment for pre-service teachers in this study, it is likely that they were more engaged in the learning process and more cognisant of their increased confidence and competence to teach physical education.

Reflection is an essential element of an authentic learning environment (Herrington, et al., 2014). Furthermore, developing the ability to think about why and what one does is considered vital to intelligent teaching practice (K. Zeichner, 1987; K. Zeichner and Liston, 1987; K. Zeichner and Tabachnick, 1991). Through his exploration of assessment in HE, Tummons (2011) promotes the significance of reflective practice in professional courses such as teacher education, especially when reflective practice is taught and practiced in authentic learning environments (Tummons, 2011). For example, Tummons explains that reflective practices can be effective for facilitating learning when teacher education students evaluate sessions they have delivered in school through a response to an observer's feedback. Cochran-Smith et al. (2015) assert quality teacher preparation should be a collaborative process with groups of students sharing ideas, articulating their reasoning for pedagogical decisions, engaging in problem solving and reflecting on their own practice. However, there is limited evidence for effective strategies for developing self-reflective skills in the context of HE teacher education programs (Standal and Moe, 2013). In this study we embedded instruction and practice around the effective use of dialogical feedback (academic and peer) and reflective practice within four existing undergraduate physical education courses. In doing so prior to school teaching visits, the research team 
ensured that students in this study were well prepared for providing, receiving and using feedback to improve their knowledge, skills and understandings of teaching children. The improvements in self-perceptions of teaching ability and confidence resulting in this study reinforce the value of using this approach for improving the quality of physical education courses, and for facilitating learning and development in students.

There is strong evidence supporting that feedback is a key element of student learning, where a student's performance generally improves as a result of receiving, understanding and acting on feedback provided (Adcroft, 2011). The quality of the feedback provided and the receptiveness of the student to take on feedback determines the impact on learning and on improvements of future performances. Students and staff in HE across the globe report dissatisfaction with current methods of providing feedback. Common issues relating to poor feedback practices, inconsistency in understanding and expectations of feedback between academics and students, students not collecting or using feedback provided, and the lack of opportunity to use feedback are common complaints highlighted in the literature (Burke, 2009; Evans, 2013; Vardi, 2009). Given the positive findings of this study and the evidence supporting the facilative role feedback plays in changing the behaviour of students in the learning cycle, creating a stimulating and authentic learning environment where dialogical feedback is used to promote self-reflection and development in teacher education programs is a novel and effecacious approach (Adcroft, 2011). Furthermore, this study demonstrates that dialogical feedback provided by academics and peers are equally impactful on improving the self-perceptions of teaching competence and confidence in pre-service teachers delivering physical education. In the past, academic feedback (usually written feedback) has dominated in HE, but these findings support that peer feedback may provide an effective option for providing feedback on teaching performances, especially when used as an assessment for learning tool.

Process evaluation results show high levels of participant satisfaction with the authentic learning environment (in-school teaching) and dialogical feedback embedded in physical edcuation courses in this study. Students reported valuing the authentic teaching experience for their learning and for building confidence. Students particularly liked the 'hands-on' and practical nature of the learning experience - with many students describing the learning experience as "relevant" and "real-life". Pre-service teachers in this study also provided an abundance of positive feedback for the use of dialogical feedback, especially PDA. As with our previous study (Eather, et al., 2017), participants indicated that they appreciated the constructive feedback and new ideas discussed with peers, and were happy to have "honest" and "immediate" feedback. Several students also reported feeling more comfortable with peer feedback ("less nerve racking and intimidating") and appreciated the opportunity to explain their teaching strategies. Although the negative feedback for PDA was limited, a few participants reported a dislike of PDA because they were not receiving "professional feedback" or they had "difficulty communicating negative feedback to peers". The qualitative feedback on academic dialogue was all positive, with participants reporting that the feedback was always "relatable and helpful", and they appreciated the opportunity to "discuss complex and new ideas and theories in simple and easy to understand terms with the tutor." Previous studies support that learners are often more open to receiving judgement when it is provided by people that they trust and when it facilitates learning (Carless, 2006). In this study, the benefits of embedding dialogical feedback and the development of reflective practices in a positive and supportive environment thoughout the entirety of semester long physical education courses has been effective and well-received. It is important to note that the feedback provided by peers was not used in the formal assessment of students teaching performances (this was performed by an academic), but was merely used as an information source (to inform future practices and for the formal written evaluation and reflection of the experience). In Cartney's (2010) case study, peer-assessments were linked formally to grades in a university course, and participants reported increased levels of anxiety and anger during peer-assessment (Cartney, 2010). The approach in this study was driven by the desire to create a positive and non-judgemental learning environment.

A positive development from previous studies investigating PDA, was that participants in this study were able to use questioning to effectively stimulate discussion (Cartney, 2010; Eather, et al., 2017). In our previous study of PDA we found inconsistency in the quality of the feedback provided by pre-service teachers, with the majority struggling to facilitate dialogue through questioning and discussion (rather than providing comments) (Cartney, 2010). In the current study however, most students posed relevant and thought-provoking questions (e.g., "How could you improve active learning time?" and "At the end, you had all the girls plus one boy and then lots of boys. What was the idea behind separating them like that?"). It is clear that an increased focus (and time spent practicing) on developing high quality questions in the current study, improved the quality of dialogue. Consequently, learning and developing self-reflective skills, evaluative skills and the ability to use dialogue effectively during a teacher education program is likely to enhance a graduate's success in their future teaching careers. 


\section{Limitations}

Although the strength of this study is its novelty (comparing two types of dialogical feedback), the lack of control group (receiving no feedback) is a limitation. Ethically, it was not possible to remove feedback entirely, especially given that academic feedback is standard practice in physical education courses. This study also extends on previous work by including a large sample of both primary and secondary pre-service teachers, but the single institution and subject area (physical education), limits the generalizability of the results. Future multi-site randomised controlled trials are needed to build the evidence for dialogical feedback, and to investigate the impact of this feedback strategy for effecting actually teaching competencies.

\section{Conclusion}

Creating authentic learning environments in HE is a priority, especially in teacher education programs. Assessment and feedback that supports learning are also essential components of the learning process. This study provides evidence to support the use of peer and academic delivered dialogical feedback in in-school teaching experiences in pre-service physical education courses. The findings indicate the use of dialogical feedback increases pre-service teachers' confidence and competencies required to teach. Furthermore, peer and academic delivered dialogical feedback were well liked and valued by pre-service teachers, and in combination with an authentic and positive learning environment, may contribute to learning and development. To ensure that students receive all the benefits of PDA and AF, and to ensure that students do not miss the expertise of the academic, a combination of both feedback methods could be utilised in HE courses. This is the first study to systematically compare peer and academic delivered dialogical feedback, and may help inform future assessment practices within HE courses in physical education and in other disciplines.

\section{References}

Adcroft, A. (2011). The mythology of feedback. Higher Education Research \& Development, 30(4), pp. 405-419. https://doi.org/10.1080/07294360.2010.526096

Archer, J. C. (2010). State of the science in health professional education: effective feedback. Medical Education, 44(1), pp. 101-108. https://doi.org/10.1111/j.1365-2923.2009.03546.x

Ashenafi, M. M. (2017). Peer-assessment in higher education - twenty-first century practices, challenges and the way forward. Assessment \& Evaluation in Higher Education, 42(2), 226-251. https://doi.org/10.1080/02602938.2015.1100711

Ashford-Rowe, K., Herrington, J., \& Brown, C. (2014). Establishing the critical elements that determine authentic assessment. Assessment \& Evaluation in Higher Education, 39(2), 205-222. https://doi.org/10.1080/02602938.2013.819566

Bailey, R., Armour, K., Kirk, D., Jess, M., Pickup, I., Sandford, R., . . Sport Pedagogy Special Interest, G. (2009). The educational benefits claimed for physical education and school sport: an academic review. Research Papers in Education, 24(1), 1-27. https://doi.org/10.1080/02671520701809817

Bandura, A. (1977). Self-efficacy: toward a unifying theory of behavioral change. Psychological Review, 84(2), 191-215. https://doi.org/10.1037/0033-295X.84.2.191

Black, P., \& Wiliam, D. (1998). Assessment and classroom learning Assessment in Education: Principles, Policy \& Practice, 5, 7-75. https://doi.org/10.1080/0969595980050102

Blair, A., \& McGinty, S. (2013). Feedback-dialogues: exploring the student perspective. Assessment \& Evaluation in Higher Education, 38(4), 466-476. https://doi.org/10.1080/02602938.2011.649244

Bok, H. G. J., Teunissen, P. W., Spruijt, A., Fokkema, J. P. I., van Beukelen, P., Jaarsma, D. A. D. C., \& van der Vleuten, C. P. M. (2013). Clarifying students' feedback-seeking behaviour in clinical clerkships. Medical Education, 47(3), 282-291. https://doi.org/10.1111/medu.12054

Boud, D. (2015). Feedback: ensuring that it leads to enhanced learning. The Clinical Teacher, 12(1), 3-7. https://doi.org/10.1111/tct.12345

Boud, D., \& Falchikov, N. (2007). Rethinking Assessment in Higher Education: Learning for the Longer Term: Taylor \& Francis. https://doi.org/10.4324/9780203964309

Boud, D., \& Molloy, E. (2013). Rethinking models of feedback for learning: the challenge of design. Assessment \& Evaluation in Higher Education, 38(6), 698-712. https://doi.org/10.1080/02602938.2012.691462

Brown, S. (2010). Afterword. Assessment \& Evaluation in Higher Education, 35(3), 347-349. https://doi.org/10.1080/02602931003690835 
Burke, D. (2009). Strategies for using feedback students bring to higher education. Assessment \& Evaluation in Higher Education, 34(1), 41-50. https://doi.org/10.1080/02602930801895711

Carless, D. (2006). Differing perceptions in the feedback process. Studies in Higher Education, 31(2), 219-233. https://doi.org/10.1080/03075070600572132

Carless, D., Salter, D., Yang, M., \& Lam, J. (2011). Developing sustainable feedback practices. Studies in Higher Education, 36(4), 395-407. https://doi.org/10.1080/03075071003642449

Cartney, P. (2010). Exploring the use of peer assessment as a vehicle for closing the gap between feedback given and feedback used. Assessment \& Evaluation in Higher Education, 35, 551-564. https://doi.org/10.1080/02602931003632381

Claxton, G., Chambers, M., Powell, G., \& Lucas, B. (2011). The Learning Power School- Pioneering 21 st Century Education. Retrieved from http://lnnz2.vivid.net.nz/shared/professionalReading/GCMCBLP.pdf

Cochran-Smith, M., Villegas, A. M., Abrams, L., Chavez-Moreno, L., Mills, T., \& Stern, R. (2015). Critiquing teacher preparation research: An overview of the field, Part II. Journal of Teacher Education, 66(2), 109-121. https://doi.org/10.1177/0022487114558268

Costa, A. L., \& Garmston, R. J. (2002). Cognitive coaching: A foundation for renaissance schools (3rd ed.) Norwood, MA: Christopher-Gordon, Inc.

Darling-Hammond, L. (2000). Teacher Quality and Student Achievement. [Academic Achievement; Educational Policy; Elementary Secondary Education; State Programs; Teacher Effectiveness]. 8. https://doi.org/10.14507/epaa.v8n1.2000

Darling-Hammond, L. (2006). Powerful teacher education: Lessons from exemplary programs San Francisco, CA: Jossey-Bass.

Doan, L. (2013). Is feedback a waste of time? The students' perspective. [Tutor Feedback; Feedback Perceptions; Student Response; Guidance on Feedback]. Journal Of Perspectives In Applied Academic Practice, 1(2), 3-10. https://doi.org/10.14297/jpaap.v1i2.69

Dudley, D., Okely, A., Pearson, P., \& Cotton, W. (2011). A systematic review of the effectiveness of physical education and school sport interventions targeting physical activity, movement skills and enjoyment of physical activity. European Physical Education Review, 17(3), 353-378. https://doi.org/10.1177/1356336X11416734

Eather, N., Riley, N., Miller, D., \& Jones, B. (2017). Evaluating the effectiveness of using peer-dialogue assessment (PDA) for improving pre-service teachers' perceived confidence and competence to teach physical education. Australian Journal of Teacher Education, 42(1). https://doi.org/10.14221/ajte.2017v42n1.5

Ellery, K. (2008). Assessment for learning: a case study using feedback effectively in an essay-style test. Assessment \& Evaluation in Higher Education, 33, 421-429. https://doi.org/10.1080/02602930701562981

Evans, C. (2013). Making sense of assessment feedback in higher education. Review of Educational Research, 83(1), 70-120. https://doi.org/10.3102/0034654312474350

Gielen, S., Peeters, E., Dochy, F., Onghena, P., \& Struyven, K. (2010). Improving the effectiveness of peer feedback for learning. Learning and Instruction, 20(4), 304-315. https://doi.org/10.1016/j.learninstruc.2009.08.007

Hand, K. (2014). Building confident teachers: Preservice physical education teachers' efficacy beliefs. Journal of Case Studies in Education, 6(September), 1-9.

Hattie, J. (2003 October) Distinguishing expert teachers from novice and experienced teachers. Teachers make a difference. What is the research evidence? Paper presented at the Australian Council for Educational Research Annual Conference on Building Teacher Quality, Melbourne, Australia.

Hattie, J., \& Timperley, H. (2007). The power of feedback. Review of Educational Research, 77(1), 81-112. https://doi.org/10.3102/003465430298487

Herrington, J., Parker, J., \& Boase-Jelinek, D. (2014). Connected authentic learning: Reflection and intentional learning. Australian Journal of Education, 58(1), 23-35. https://doi.org/10.1177/0004944113517830

Higgins, R., Hartley, P., \& Skelton, A. (2002). The Conscientious Consumer: Reconsidering the role of assessment feedback in student learning. Studies in Higher Education, 27(1), 53-64. https://doi.org/10.1080/03075070120099368

Institute of Medicine. (2013). Educating the student body: Taking physical activity and physical education to school. Washington, DC.: T. N. A. Press. file:///C:/Users/ne599/Downloads/18314.pdf 
Iucu, R. B., \& Marin, E. (2014). Authentic Learning in Adult Education. Procedia - Social and Behavioral Sciences, 142, 410-415. https://doi.org/10.1016/j.sbspro.2014.07.702

Jenkinson, K., \& Benson, A. C. (2010). Barriers to providing physical education and physical activity in Victorian state secondary schools. Australian Journal of Teacher Education, 35(8), 1-17. https://doi.org/10.14221/ajte.2010v35n8.1

Kluger, A. N., \& DeNisi, A. (1996). The effects of feedback interventions on performance: A historical review, a meta-analysis, and a preliminary feedback intervention theory. Psychological bulletin, 119(2), 254-284. https://doi.org/10.1037/0033-2909.119.2.254

Long, P. (2014). Staff and students' conceptions of good written feedback: Implications for practice. Practitioner Research in higher Education Journal, 8(1), 54-63. Retrieved from http://194.81.189.19/ojs/index.php/prhe/article/view/168/290

Lubans, D. R., Lonsdale, C., Cohen, K., Eather, N., Beauchamp, M. R., Morgan, P. J., ... Smith, J. J. (2017). Framework for the design and delivery of organized physical activity sessions for children and adolescents: rationale and description of the 'SAAFE' teaching principles. Int J Behav Nutr Phys Act, 14(1), 24. https://doi.org/10.1186/s12966-017-0479-x

McAleese , M., Bladh, A., Berger, V., Bode, C., Muehlfeit, J., Petrin, T., ... Tsoukalis, L. (2013). Report to the European Commission on improving the quality of teaching and learning in Europe's higher education institutions. Luxembourg

McDowell, L., Smailes, J., Sambell, K., Sambell, A., \& Wakelin, D. (2008). Evaluating assessment strategies through collaborative evidence-based practice: can one tool fit all? Innovations in Education and Teaching International, 45(2), 143-153. https://doi.org/10.1080/14703290801950310

McDowell, L., Wakelin, D., Montgomery, C., \& King, S. (2011). Does assessment for learning make a difference? The development of a questionnaire to explore the student response. Assessment \& Evaluation in Higher Education, 36(7), 749-765. https://doi.org/10.1080/02602938.2010.488792

Merry, S., Price, M., Carless, D., \& Taras, M. (2013). Reconceptualising Feedback in Higher Education : Developing Dialogue with Students London, UNITED KINGDOM: Routledge. https://doi.org/10.4324/9780203522813

Miller, A., Eather, N., Gray, S., Sproule, J., Williams, C., Gore, J., \& Lubans, D. R. E. (2016). Can continuing professional development utilizing a game-centred approach improve the quality of physical education teaching delivered by generalist primary school teachers? European Physical Education Review, 1-12. https://doi.org/10.1177/1356336X16642716

Molloy, E., \& Boud, D. (2013). Seeking a different angle on feedback in clinical education: the learner as seeker, judge and user of performance information. Medical Education, 47(3), 227-229. https://doi.org/10.1111/medu.12116

Morgan, P. J., \& Bourke, S. F. (2005). An investigation of pre-service and primary school teachers' perspectives of PE teaching confidence and PE teacher education. ACHPER Healthy Lifestyle Journal, 52(1), 1-7. https://doi.org/10.1080/17408980701345550

Morgan, P. J., \& Bourke, S. F. (2008). Non-specialist teachers' confidence to teach PE: the nature and influence of personal school experiences in PE. Physical Education and Sport Pedagogy, 13(1), 29. https://doi.org/10.1080/17408980701345550

Morgan, P. J., \& Hansen, V. (2007). Recommendations to improve primary school physical education: the classroom teacher's perspective the classroom teacher's perception. The Journal of Educational Research, 101(2), 99-112. https://doi.org/10.3200/JOER.101.2.99-112

Nicol, D. (2009). Transforming assessment and feedback: Enhancing integration and empowerment in the first year. Mansfield, NG: T. Q. A. A. f. H. Education.

http://www.enhancementthemes.ac.uk/pages/docdetail/docs/publications/transforming-assessment-and-feedback

Nicol, D. (2010). From monologue to dialogue: improving written feedback processes in mass higher education. Assessment \& Evaluation in Higher Education, 35(5), 501-517. https://doi.org/10.1080/02602931003786559

Orsmond, P., Maw, S. J., Park, J. R., Gomez, S., \& Crook, A. C. (2013). Moving feedback forward: theory to practice. Assessment \& Evaluation in Higher Education, 38(2), 240-252. https://doi.org/10.1080/02602938.2011.625472

Orsmond, P., Merry, S., \& Reiling, K. (2005). Biology students' utilization of tutors' formative feedback: a qualitative interview study. Assessment \& Evaluation in Higher Education, 30(4), 369-386.

https://doi.org/10.1080/02602930500099177 
Ozder, H. (2011). Self-efficacy beliefs of novice teachers and their performance in the classroom. Australian Journal of Teacher Education, 36(5), 1-16. https://doi.org/10.14221/ajte.2011v36n5.1

Price, M., Handley, K., \& Millar, J. (2011). Feedback: focusing attention on engagement. Studies in Higher Education, 36(8), 879-896. https://doi.org/10.1080/03075079.2010.483513

Price, M., Handley, K., Millar, J., \& O'Donovan, B. (2010). Feedback: All that effort, but what is the effect? Assessment and Evaluation in Higher Education, 35(3), 277-289. https://doi.org/10.1080/02602930903541007

Rust, C. (2007). Towards a scholarship of assessment. Assessment \& Evaluation in Higher Education, 32(2), 229-237. https://doi.org/10.1080/02602930600805192

Sadler, D. R. (2010). Beyond feedback: developing student capability in complex appraisal. Assessment \& Evaluation in Higher Education, 35(5), 535-550. https://doi.org/10.1080/02602930903541015

Sanders, W. L., Wright, S. P., \& Horn, S. P. (1997). Teacher and classroom context effects on student achievement: Implications for teacher evaluation. [journal article]. Journal of Personnel Evaluation in Education, 11(1), 57-67. https://doi.org/10.1023/A:1007999204543

Shepard, L. (2000). The role of assessment in a learning culture. Educational Researcher, 29, 4-14. https://doi.org/10.3102/0013189X029007004

Shulman, L. S. (1987). Knowledge and teaching: foundations of the new reform. Harvard Educational Review, 57(1), 1-23. https://doi.org/10.17763/haer.57.1.j463w79r56455411

Shute, V. J. (2008). Focus on Formative Feedback. Review of Educational Research, 78(1), 153-189. https://doi.org/10.3102/0034654307313795

Society of Health and Physical Educators (Producer). (2010, 23/01/2016). Opportunity to learn: Guidelines for elementary, middle, and high school physical education. Retrieved from http://www.shapeamerica.org/standards/guidelines/upload/Opportunity-to-Learn-Grid.pdf

Standal, Ø. F., \& Moe, V. F. (2013). Reflective practice in physical education and physical education teacher education: A review of the literature since 1995. Quest, 65(2), 220-240. https://doi.org/10.1080/00336297.2013.773530

Stein, S. J., Isaacs, G., \& Andrews, T. (2004). Incorporating authentic learning experiences within a university course. Studies in Higher Education, 29(2), 239-258. https://doi.org/10.1080/0307507042000190813

Tony, H., \& Jan, H. (Eds.). (2006). Authentic Learning Environments in Higher Education. Hershey, PA, USA: IGI Global.

Tschannen-Moran, M., \& Woolfolk Hoy, A. W. (2001). Teacher efficacy: Capturing an elusive construct. Teacher and Teacher Education, 17(7), 783-805. https://doi.org/10.1016/S0742-051X(01)00036-1

Tummons, J. (2011). 'It sort of feels uncomfortable': problematising the assessment of reflective practice. Studies in Higher Education, 36(4), 471-483. https://doi.org/10.1080/03075071003671794

van Zundert, M., Sluijsmans, D., \& van Merriënboer, J. (2010). Effective peer assessment processes: Research findings and future directions. Learning and Instruction, 20(4), 270-279.

doi:https://doi.org/10.1016/j.learninstruc.2009.08.004 https://doi.org/10.1016/j.learninstruc.2009.08.004

Vardi, I. (2009). The relationship between feedback and change in tertiary student writing in the disciplines. International Journal of Teaching and Learning in Higher Education, 20(3), 350-361. Retrieved from http://files.eric.ed.gov/fulltext/EJ869319.pdf

Weaver, M. R. (2006). Do students value feedback? Student perceptions of tutors' written responses. Assessment \& Evaluation in Higher Education, 31(3), 379-394. https://doi.org/10.1080/02602930500353061

Whitehead, S. H., \& Biddle, S. (2008). Adolescent girls' perceptions of physical activity: A focus group study. European Physical Education Review, 14(2), 243-262. https://doi.org/10.1177/1356336X08090708

Wiliam, D. (2017). Learning and assessment: a long and winding road? Assessment in Education-Principles Policy \& Practice, 24(3), 309-316. https://doi.org/10.1080/0969594X.2017.1338520

Zeichner, K. (1987). Preparing reflective teachers: An overview of instructional strategies which have been employed in preservice teacher education. International Journal of Educational Research, 11, 567-575. https://doi.org/10.1016/0883-0355(87)90016-4

Zeichner, K. (2010). Rethinking the connections between campus courses and field experiences in college- and university-based teacher education. Journal of Teacher Education, 61(1-2), 89-99. 
https://doi.org/10.1177/0022487109347671

Zeichner, K., \& Liston, D. (1987). Teaching student teachers to reflect. Harvard Educational Review, 57, 23-48. https://doi.org/10.17763/haer.57.1.j18v7162275t1w3w

Zeichner, K., \& Tabachnick, B. R. (1991). Reflections on reflective teaching In K. Zeichner \& B. R. Tabachnick (Eds.), Issues and Practices in Inquiry-oriented Teacher Education (1-21). London: Falmer Press.

\section{Copyrights}

Copyright for this article is retained by the author(s), with first publication rights granted to the journal.

This is an open-access article distributed under the terms and conditions of the Creative Commons Attribution license which permits unrestricted use, distribution, and reproduction in any medium, provided the original work is properly cited. 